\title{
Investment Strategy of the Temasek Holdings
}

\author{
Martin Vozar, Jozef Komornik \\ Faculty of Management, Comenius University in Bratislava, Slovak Republic
}

\begin{abstract}
Sovereign Wealth Funds (SWFs) are generally known as investment funds owned by national governments and financed by the country's foreign currency reserves (dollar, euro, and yen), often through their central banks or via direct investments. The study investigated the investment strategy of the Temasek Holdings as one of the most successful SWFs which is owned by the government of Singapore. Temasek Holdings was founded in 1974 to manage part of the government's revenues. Present turbulent times create a big pressure on healthy investment strategy of the SWFs. But total shareholder return for Temasek since its inception in 1974 has been a healthy 17\% compounded annually. The main objective of the paper is to focus on the role of the Temasek Holdings as a company managed on commercial principles with an aim to achieve long-term sustainable returns. The study also analyzed Temasek Holdings'investment strategy. The study provides answers to questions like: why Temasek is of the most successful SWFs and what is the fund risk management? Another part of the paper compares investment strategy of the Temasek Holdings with other SWFs. The study has been conducted mainly on the basis of literature survey, secondary information and with using various web sites and research paper. The analysis has been also based on disclosures appearing in the Temasek annual reports over the period from 2008 to 2010.
\end{abstract}

Keywords: sovereign wealth funds (SWFs), Temasek, strategy, investment portfolio, asset under management

\section{Introduction}

Sovereign Wealth Funds (SWFs) are generally known as investment funds owned by national governments and financed by the country's foreign currency reserves (dollar, euro, and yen), often through their central banks or via direct investments. Usually the funds are invested in the proceeds of non-renewable natural resources or a higher return alternative to holding foreign currency (Balding, 2008). The term sovereign wealth fund was introduced in 2005, but the first SWFs was introduced in 1953 by the government of Kuwait (Kuwait Investment Authority, a commodity SWFs) (Johnson, 2007). Expansion of sovereign wealth funds in recent years has been driven by ballooning East Asian foreign exchange reserves and the need for oil rich countries to invest oil money to provide income to replace that from diminishing oil reserves. These funds are now major players in the world financial markets. The combined assets of the major SWFs (owned by 20 governments) have reached over three trillion dollars, and are expected to reach over 10 trillion dollars by 2012. Although the current total amount makes up only some three percent of the world's traded securities, the SWFs already have tremendous

\footnotetext{
Martin Vozar, Ph.D., Assistant Professor, Faculty of Management, Comenius University in Bratislava. Jozef Komornik, Professor, Dean, Faculty of Management, Comenius University in Bratislava.

Correspondence concerning this article should be addressed to Martin Vozar, Fakulta managementu UK, Odbojárov 10, P.O.BOX 95, 82005 Bratislava 25. E-mail: martin.vozar@fm.uniba.sk.
} 
concentrated financial power. Over half of the SWFs assets are owned by oil and gas exporting nations, and about one third by Australia, China, and Singapore. SWFs are aggressive investors and have bought into firms as diverse as Morgan Stanley, General Electric, and Sony.

Although there exists no commonly accepted definition of SWFs, three elements can be identified that are common to such funds. First, SWFs are state-owned. Second, SWFs have no or only very limited explicit liabilities, and third, SWFs are managed separately from official foreign exchange reserves. In addition, most SWFs share certain characteristics that originate in the specific nature of SWFs. For example, the lack of explicit liabilities (or the stretched out maturity of liabilities) favours the pursuit of long-term investment strategies, as implemented by most SWFs (Johnson, 2007). In this respect, sovereign wealth funds differ from sovereign pension funds that operate subject to explicit liabilities and a continuous stream of fixed payments, making sovereign wealth funds more similar to private mutual funds. Second, the absence of explicit liabilities also has a bearing on the willingness to take risk, as standard portfolio theory predicts a higher share of fixed income securities for funds that are subject to recurring payments. Finally, most sovereign wealth funds appear to have substantial exposure to foreign investments or are even entirely invested in foreign assets (Ziemba, 2008).

\section{Objectives of the Study}

The main objective of the paper is to focus on the SWFs_-Temasek Holding. The specific objectives are:

- To portray the role of the SWFs in global economy;

- To study the SWFs environment from the broad picture;

- To analyze investment strategy, portfolio, and risk management of the Temasek Holding;

- To analyze financial condition of the Temasek Holding.

\section{Methodology of the Study}

The main objective of the paper is to focus on the role of the Temasek Holdings as a company managed on commercial principles with an aim to achieve long-term sustainable returns. The study also analyzed Temasek Holdings investment strategy. The study provides answers to questions like: why is Temasek so successful SWFs and what is the fund risk management? Another part of the paper compares investment strategy of the Temasek Holdings with others SWFs. The study has been conducted mainly on the basis of literature survey, secondary information and with using various web sites and research paper. The analysis has been also based on disclosures appearing in the Temasek annual reports over the period 2008 to 2010.

\section{Overview of SWFs Environment}

The main group of countries that have established SWFs are resource-rich economies which currently benefit from high oil and commodity prices. In these countries, SWFs partly also serve the purpose of stabilising government and export revenues which would otherwise mirror the volatility of oil and commodity prices (Balding, 2008). Another purpose of such funds in resource-rich countries is the accumulation of savings for future generations as natural resources which are non-renewable and are hence anticipated to be exhausted after some time. Prominent examples of such SWFs include Norway's Government Pension Fund, investment agencies set up by member countries of the Gulf Cooperation Council, such as the Abu Dhabi Investment 
Authority which manages the foreign assets of the Emirate of Abu Dhabi in the United Arab Emirates, and the Russian oil stabilisation fund which has recently been partly transformed into a fund for future generations. A second group of countries, most notably in Asia, have established SWFs because reserves are accumulated in excess of what may be needed for intervention or balance-of-payment purposes. The source of reserve accumulation for these countries is mostly not linked to primary commodities but rather related to the management of inflexible exchange rate regimes. As the authorities have become more comfortable with reserve levels, foreign assets have been moved to specialised agencies which often have explicit return objectives and may invest in more risky assets than central banks. Prominent examples include funds that have been operating for decades, such as the Singapore Government Investment Company, but also more recently established funds such as the Korea Investment Corporation, and the investment portfolio of the Exchange Fund managed by the Hong Kong Monetary Authority. Recently China has also established a new investment agency, the China Investment Corporation, responsible for the management of a portion of Chinese foreign reserves.

(USD billions) $\quad$ 口SWFs $\quad$ 口Official foreign exchange reserves

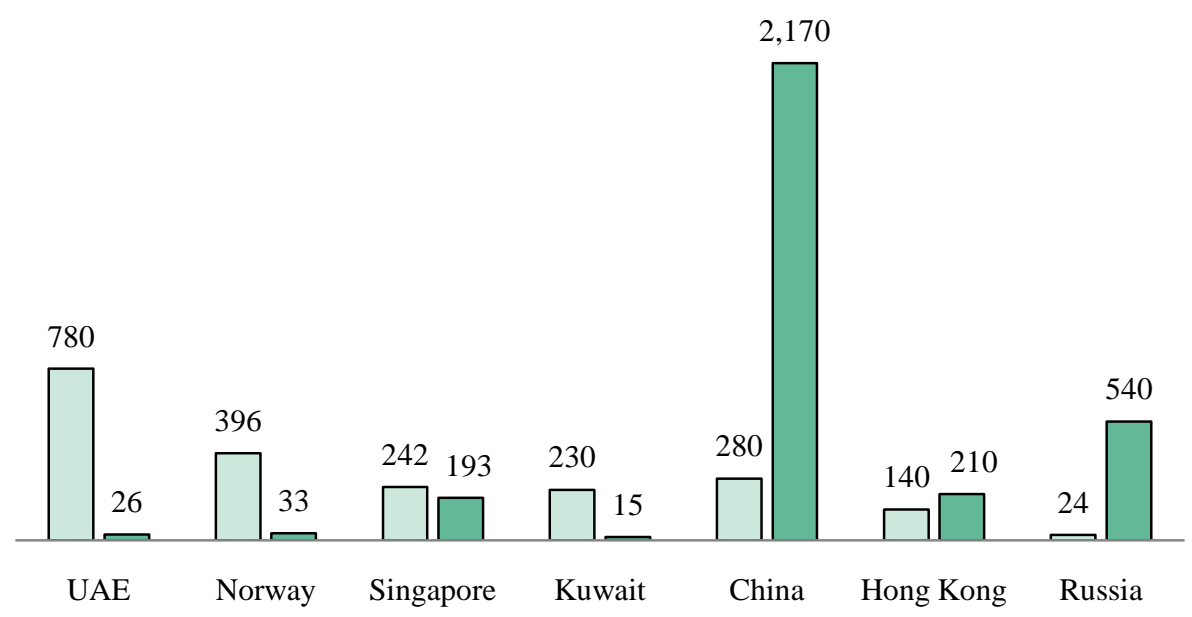

Figure 1. SWFs vs. official foreign exchange reserves (as of 2010).

\section{Amount of Asset Under Management of SWFs}

Based on a combination of private and official sources, SWFs are estimated to have accumulated between at least USD 3 trillion, compared with around USD 5 trillion in traditional foreign exchange reserves. Comparing the level of traditional foreign exchange reserves with assets managed in SWFs, two observations stand out (see Figure 1). Some countries have been accumulating foreign assets in SWFs for a long time and therefore hold relatively modest levels of foreign exchange reserves (e.g., members of the Gulf Cooperation Council like the UAE and Kuwait). In contrast, other countries have accumulated sizeable holdings of traditional foreign exchange reserves-most likely in excess of precautionary levels-but only recently created SWFs with relatively modest levels of assets under management (e.g., China and Russia). Therefore, many observers expect that these countries may in the future increasingly accumulate foreign assets in SWFs or even shift traditional reserve assets into such funds (Aizenman, 2008). Oil exporters, mostly from the Middle East, but also Norway's sizeable Government Pension Fund, are estimated to account for the largest part of total assets managed by SWFs. 
A smaller fraction of around USD 700 billion is accounted for by Asian emerging economies, most notably Singapore, which has been running SWFs since the 1970s. But also mature economies, other than Norway's, have set up SWFs, mostly to save receipts from the exploitation of natural resources. In sum, a plausible estimate of total assets managed by SWFs ranges from USD 3 to 4 trillion (Ziemba, 2008).

\section{Selected Sovereign Wealth Funds by Country of Residence}

\section{Singapore}

The Government of Singapore owns two independent SWFs. The first, Temasek Holdings, was founded in 1974 to manage part of the government's revenues. To satisfy legal requirements in issuing bonds, Temasek first reported its accounts to the public in 2004. Total annualised returns have been $18 \%$ per annum since its inception, and currently the fund has a net asset value of around USD 133 billion. Although Temasek originally invested domestically, foreign investments now account for more than half of its total portfolio, concentrated on emerging Asia, especially China, Taiwan, and Korea, and from a sectoral viewpoint, in the financial and telecommunications industries. Temasek claims not to direct the commercial or operational decisions of portfolio companies, except where shareholder's approval is specifically required. In 1981 a second SWFs, the Government Investment Company (GIC), was set up to manage part of Singapore's foreign exchange reserves. Although its accounts are not published, GIC reports show that this fund manages a portfolio of more than USD 100 billion. The GIC's investment target is to achieve a real return of above GDP-weighted inflation. GIC claims to have constantly exceeded the benchmark return.

\section{Hong Kong}

Reserve management in Hong Kong is centralised in the Hong Kong Monetary Authority's Exchange Fund. The fund is split into a "backing portfolio" consisting of traditionally managed foreign exchange reserves, which fully back the Hong Kong dollar monetary base, and an actively managed "investment portfolio". Management of the investment portfolio is partly carried out by Hong Kong Monetary Authority staff and external fund managers. The latter is responsible for the management of all equity investments, which account for around a third of the investment portfolio.

\section{Russia}

Russia introduced a formal Oil Stabilisation Fund in January 2004 with the aim of saving the fiscal windfall gains from high oil prices. Prior to that, Russia used to operate a less formal framework aimed at smoothing the macroeconomic impact of oil price fluctuations ("special reserve"). The Oil Stabilisation Fund is mainly financed from two sources: oil export custom duties in excess of a reference price and the mineral extraction tax. In addition, the unspent fiscal surplus of the previous fiscal year is added to the Oil Stabilisation Fund. Accumulated funds may be used to finance the federal budget deficit if the oil price falls below the reference price. If the Oil Stabilisation Fund's balance exceeds RUB 500 billion, these funds can be used to prepay external debt. Since February 2008, the fund has been split into a "Reserve Fund" and a "Future Generations Fund". The Future Generations Fund can invest in sticky assets but has so far maintained a prudent asset allocation. At the same time, the Reserve Fund continues to invest in low-yielding, low-risk government bonds. 


\section{Norway}

Norway's Government Pension Fund was established in 1990. Since January 2006, this fund includes the Government Pension Fund-Global (formerly Government Petroleum Fund, established in 1990) and the Government Pension Fund-Norway (formerly National Insurance Scheme Fund). The fund receives central government revenues from petroleum activities. As regards its objectives, the fund is used primarily as a savings fund for future generations. Only can the expected real return of the fund normally be transferred to the central government budget and used for general budgetary purposes. The Government Pension Fund-Global attained a portfolio value of around USD 423 billion at end of 2009. The day-to-day management is delegated to Norges Bank but the ultimate responsibility lies with the Ministry of Finance, which issues guidelines for the investment of the fund's capital in shares and other securities abroad. Its institutional set-up is often quoted as a benchmark in terms of transparency and accountability. The fund publishes quarterly and annual reports which include a detailed disclosure of assets under management, the currency and asset class composition of the portfolio down to company level and a standardised reporting of its performance against a benchmark.

\section{SWFs-Temasek Holdings}

Temasek is an investment holding company with characteristic of SWFs and with a portfolio of investments covering a wide range of countries and industry sectors. Temasek was established to create and maximize long-term shareholder value as an active investor and shareholder of successful enterprises. Headquartered in Singapore, Temasek was formed by the Government in 1974 to separately hold and manage its investments in companies and joint ventures (Temasek is wholly-owned by the government through the Minister of Finance-MOF, under the Singapore Companies Act). This move freed the government to focus on the economy as a whole and provided an opportunity for a commercially disciplined and independent company to achieve sustainable long-term returns. In addition to managing its inherited portfolio, Temasek also actively invested in other local companies in Singapore for growth and diversification. As Singapore's economy evolved and became increasingly globalized, Temasek began to invest actively outside of Singapore. Temasek has been assigned an overall corporate credit rating of “Aaa” by Moody’s and “AAA” by Standard \& Poor's. From an initial portfolio of US\$350 million in 1974 which is made up of various Singapore start-ups, Temasek’s investment exposure has grown over the last 30 years into a globally diversified portfolio of about US\$133 billion (as of March 31, 2010), covering a range of industries, including financial services, transport and logistics, telecommunications and other infrastructure and engineering services. Total shareholder return of the Temasek Holdings since its inception has been $17 \%$ compounded annually. Singapore and Asia account for nearly 80 percent of Temasek's investments, while developed markets such as the United States and Europe are a long-standing and growing part of Temasek portfolio.

\section{Financial Background}

The Temasek had total assets of US $\$ 203.4$ billion as of March 31, 2010. The Temasek generated revenue of US $\$ 54.8$ billion and profit attributable to equity holder of Temasek of US\$3.3 billion for the year ended on March 31, 2010. Temasek’s Net Portfolio Value amounted to US\$133 billion as of March 31, 2010, compared to US\$130 billion as of March 31, 2009. As of March 31, 2010, approximately 32\% of net portfolio value was in 
Singapore, 46\% in Asia (excluding Singapore and Japan), 20\% in the Organization for Economic Cooperation and Development (“OECD”) economies (excluding Korea, Mexico, and Chile) and 2\% in other markets. As of March 31, 2010, the top three sectors (based on contribution of each sector to Temasek's net portfolio value) were financial services, telecommunications, media and technology, and transportation and industrials which comprised 37\%, 24\%, and 18\%, respectively. Temasek has delivered a total shareholder return of $17 \%$ by market value and 16\% by shareholder funds compounded annually since its inception on March 31, 2010.

\section{Analysis of the Temasek Investment Strategy}

Temasek is an SWFs which is managed on commercial principles to create and deliver sustainable long-term value for its stakeholders. Temasek is an active value-oriented shareholder and investor, which seeks to manage its investments to create and maximize shareholder value, balancing risks and opportunities across industries and geographies. Temasek is an active shareholder and aims to achieve sustainable returns by engaging the boards and management of its portfolio companies to foster a culture of integrity, excellence and meritocracy, maintain a clear focus on core competence, customer fulfilment, consistent value creation, and cultivate high calibre board and management leadership. In engaging the boards and management of its portfolio companies, Temasek also aims to institutionalize superior business leadership and sound corporate governance and create strategic options to build significant international or regional brands or businesses.

As a shareholder, Temasek does not participate in the day-to-day management of its portfolio companies. Companies in its portfolio are managed by their respective management, and guided by their respective boards of directors to deliver sustainable shareholder value. Temasek's decisions are guided by business tenets and commercial discipline. As the owner of its portfolio, Temasek has flexible investment horizons and the option of taking concentrated risks or remaining in cash. As an active value-oriented investor, Temasek may increase, reduce or hold its investments in companies or other assets, based on its value tests and market opportunities. Temasek may also pioneer innovative products or businesses in order to increase and improve growth and diversification of its portfolio.

Temasek centre its investment strategies on these four investment themes:

(1) Transforming economies-Tapping the potential of transforming economies like China, India, South East Asia, and Latin America, through investments in sectors such as financial services, infrastructure, and logistics;

(2) Growing middle income populations-Leveraging growing consumer demands through investments in sectors such as telecommunications, media and technology, and consumer and real estate;

(3) Deepening comparative advantages-Seeking out economies, businesses, and companies with distinctive intellectual property and other competitive advantages;

(4) Emerging champions - Investing in companies with a strong home base, as well as companies at inflection points, with potential to be regional or global champions.

In terms of its overall portfolio, Temasek is guided by a directional portfolio mix of 40:30:20:10. This means an exposure to Asia of about 40\%, keeping Singapore at about 30\%, maintaining OECD exposure at about 20\%, and adding exposure of up to $10 \%$ to other geographies such as Latin America, the Middle East, and Africa. Temasek believes this portfolio mix provides an approximate 50:50 exposure between mature economies and growth regions. 


\section{Temasek Investment Portfolio by Sectors}

Temasek invests across sectors including financial services; telecommunications, media and technology; transportation and industrials; consumer and real estate; energy and resources; and life sciences. The text below sets forth Temasek's top three investments by market value (in the case of listed securities) or book value (in the case of unlisted securities) in these sectors, as well as their contribution to Temasek's net portfolio value (see Figure 2), in each case as of March 31, 2010.

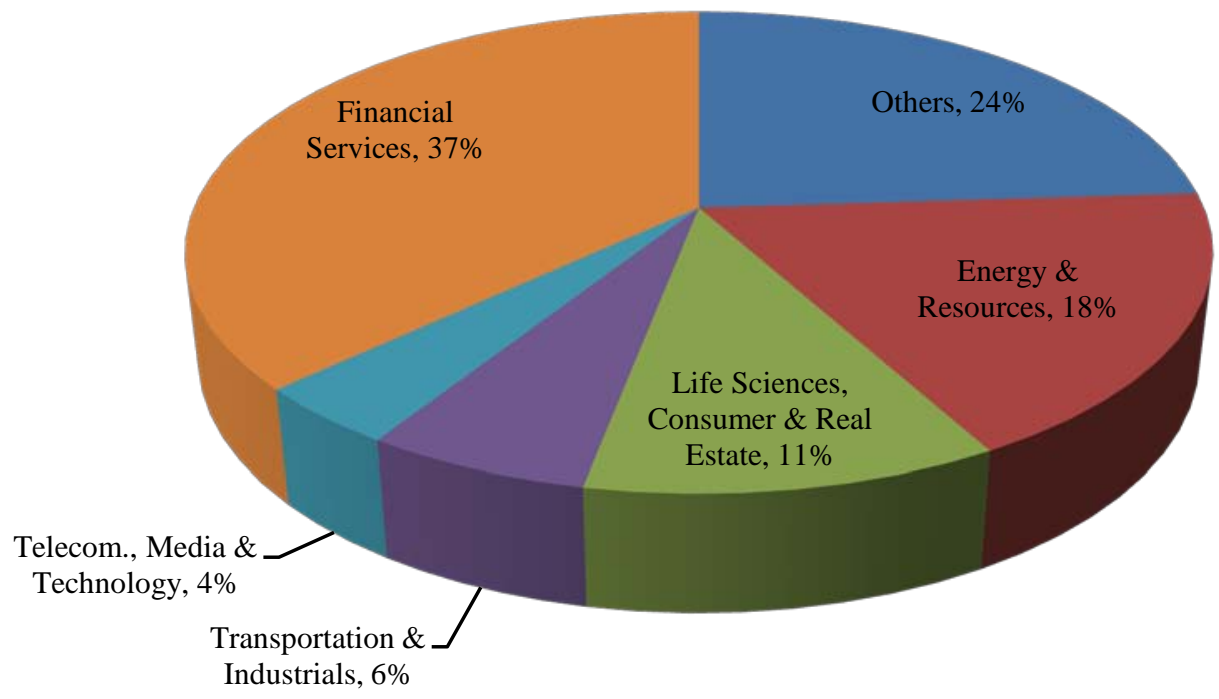

Figure 2. Temasek’s investments exposure by industry sectors as of March 31, 2010.

\section{Financial Services}

Temasek's top three investments in the financial services sector were its minority interest in each of China Construction Bank Corporation (“CCB”), Standard Chartered PLC (“Standard Chartered”) and DBS Group. Temasek’s investments in the financial services sector comprised 37\% of Temasek’s net portfolio value.

\section{Telecommunications, Media, and Technology}

Temasek's top three investments in the telecommunications, media, and technology sectors were its majority interest in each of SingTel, ST Telemedia, and STATS ChipPAC Ltd.. Temasek's investments in the telecommunications, media, and technology sectors comprised $24 \%$ of Temasek's net portfolio value.

\section{Transportation and Industrials}

Temasek's top three investments in the transportation and industrials sectors were its majority interest in each of SIA, Singapore Technologies Engineering Ltd. (“ST Engineering”) and PSA. Temasek's investments in the transportation and industrials sectors comprised 18\% of Temasek’s net portfolio value.

\section{Consumer and Real Estate}

Temasek's top three investments in the consumer and real estate sector were its majority interest in Mapletree and its minority interest in each of CapitaLand and Singapore Airport Terminal Services Ltd.. Temasek's investments in the consumer and real estate sectors comprised 11\% of Temasek's net portfolio value. 


\section{Energy and Resources \& Life Sciences}

Temasek's top three investments in the energy and resources sectors were its majority interest in Singapore Power and its minority interest in each of MEG Energy Corporation and Niko Resources Ltd.. Temasek's investments in the energy and resources sectors comprised 6\% of Temasek's net portfolio value. Temasek's top three investments in the life sciences sector were its minority interests in each of Amyris Biotechnologies Inc., Bumrungrad Hospital PCL and Interpharma Investments Ltd.. Temasek's investments in the life sciences sector comprised less than $1 \%$ of Temasek’s net portfolio value.

\section{Analysis of the Temasek Investment Portfolio}

Table 1 below sets forth the market value (in the case of listed securities) or book value (in the case of unlisted securities) of Temasek's major portfolio companies as of March 31, 2010. These companies accounted for approximately 60\% of Temasek’s net portfolio value as of March 31, 2010.

Table 1

Temasek Investment Portfolio by Major Portfolio Companies as of March 31, 2010

\begin{tabular}{lc}
\hline Company name & (S\$ million) \\
\hline Singapore Telecommunications Ltd. & 27,273 \\
China Construction Bank Corporation & 16,088 \\
Standard Chartered PLC & 13,965 \\
Singapore Airlines Ltd. & 9,780 \\
DBS Group Holdings Ltd. & 9,117 \\
PSA International Pte Ltd. & 7,985 \\
Bank of China Ltd. & 7,584 \\
CapitaLand Ltd. & 6,591 \\
PT Bank Danamon Indonesia Tbk & 4,962 \\
Singapore Technologies Engineering Ltd. & 4,824 \\
Sembcorp Industries Ltd. & 3,609 \\
\hline
\end{tabular}

Note. Source: Temasek annual report of 2009.

\section{Temasek Portfolio Performance}

Temasek's net portfolio value amounted to S\$186 billion as of March 31, 2010, compared with S\$130 billion as of March 31, 2009 (see Figure 1). As of March 31, 2010, about 77\% of Temasek’s net portfolio value comprised listed and liquid assets. One-year total shareholder return for the year ended on March 31, 2010 was approximately $42 \%$ by market value and $26 \%$ by shareholder funds. Total shareholder return by market value takes into account changes in the market value of Temasek portfolio, dividends paid, and nets off any new capital Temasek received. For unlisted investments, the movements in shareholder funds are tracked in lieu of market price changes. Over the medium term, five-year total shareholder return for the year ended on March 31, 2010 was $11 \%$ by market value and $14 \%$ by shareholder funds. Since its inception, 36-year total shareholder return for the year ended on March 31, 2010 was 17\% by market value and 16\% by shareholder funds (see Figure 4). The last 10 years Temasek in particular have seen much volatility, starting with the crash of the dotcom bubble in 2000, and ending with the pull-back from the brink of a deep global depression in 2009, punctuated in by 9/11, SARS and the H1N1 flu pandemic scare. 


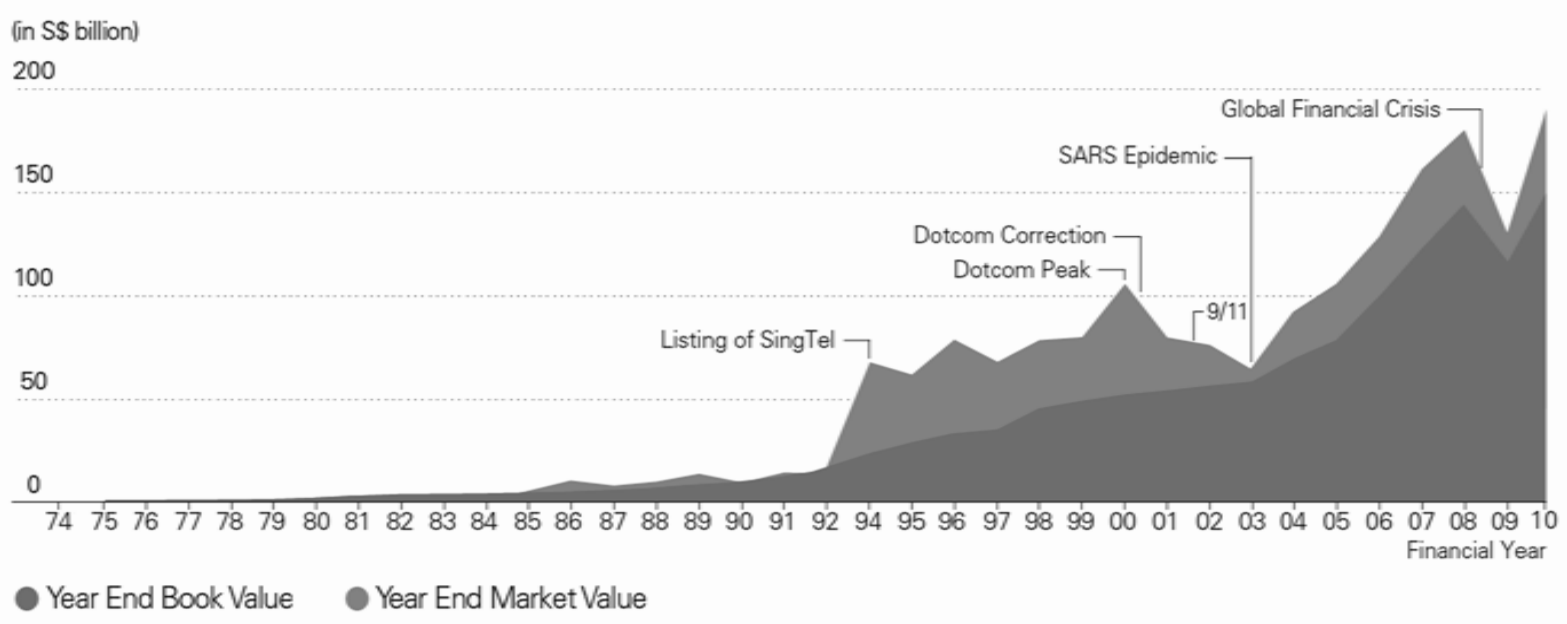

Figure 3. Development of the Temasek portfolio value over time.

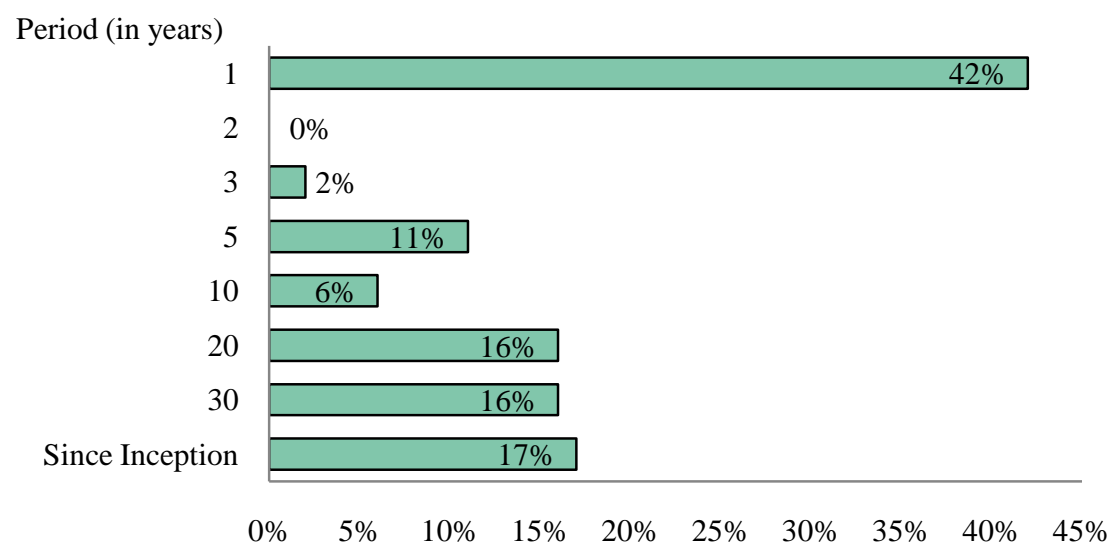

Figure 4. Temasek total shareholder return by market value.

\section{Temasek’s Portfolio Risk Management}

Financial risks of Temasek include market risks due to changes in equity prices, foreign exchange rates and interest rates. To assess its market risks, Temasek uses a VAR statistical model that estimates the potential loss on a portfolio at a given confidence level. Temasek uses an 84\% confidence interval, and Monte Carlo simulation based on three years of price data to compute its VAR for a 12-month holding period. As of March 31, 2010, Temasek’s VAR was about S\$25 billion. This implies a 16\% probability of incurring marked-to-market losses in excess of S\$25 billion, on a net portfolio value of S\$186 billion for a 12-month holding period following that date. The diversified VAR of the top 10 companies contributed over $70 \%$ of the total diversified VAR as of March 31, 2010 (2009: 70\%; 2008: 67\%; see Table 2). Apart from tracking VAR, Temasek also conducts monthly stress tests and scenario analyses to gauge monthly the effect of low probability but high impact events. In addition, Temasek reviews its overall risk position on a monthly basis and provides additional analyses of specific event, industry or country risks. In terms of credit risk management, Temasek conducts periodic reviews of its exposures related to counterparties, custodians, issuers, and countries. Temasek's investment portfolios are typically denominated in the local currency of the countries in which the investments are made. Accordingly, 
Temasek's returns on these investments, including any dividends received from these investments, are usually subject to foreign exchange rate risks.

Table 2

Temasek VAR Development by Sector and Risk Factors

\begin{tabular}{llll}
\hline Temasek VAR by Sector & 2010 & 2009 & 2008 \\
\hline Financial services & $43 \%$ & $41 \%$ & $34 \%$ \\
Transportation and industrials & $21 \%$ & $19 \%$ & $18 \%$ \\
Life Sciences, consumer and real estate & $14 \%$ & $13 \%$ & $12 \%$ \\
Telecommunications, media and technology & $14 \%$ & $19 \%$ & $28 \%$ \\
Energy and resources & $7 \%$ & $7 \%$ & $7 \%$ \\
Others & $1 \%$ & $1 \%$ & $1 \%$ \\
Total & $100 \%$ & $100 \%$ & $100 \%$ \\
\hline Temasek VAR by risk factors & 2010 & 2009 & 2008 \\
\hline Equity risk & $98 \%$ & $99 \%$ & $101 \%$ \\
Foreign exchange risk & $6 \%$ & $8 \%$ & $7 \%$ \\
Interest rate risk & $3 \%$ & $5 \%$ & $0 \%$ \\
Total diversification effects ${ }^{*}$ & $-7 \%$ & $-12 \%$ & $-8 \%$ \\
\hline
\end{tabular}

Notes. ${ }^{*}$ Diversification benefits resulting from the interactions between the equity, FX, and interest rate risk factors. Source: Temasek annual reports of 2010, 2009 and 2008.

\section{Other Sources of Risk}

As of March 31, 2010, approximately 32\% of Temasek's net portfolio value was in Singapore. Any economic recession or other deterioration in one economy-Singapore's economy could materially and adversely affect the Temasek Group's results of operations, financial position and cash flows what creates significant risk for the whole investment portfolio. The government, as a 100\% shareholder of Temasek, through MOF, can exercise control over Temasek's corporate objectives, strategies, and actions. While the government has not taken any actions in the past to influence the corporate objectives, strategies or actions of Temasek, there can be no assurance that the government will not take any actions in the future to influence the corporate objectives.

\section{Analysis of the Temasek Financial Condition}

The Temasek Group had total assets of S\$284.8 billion as of March 31, 2010. The Temasek Group generated revenue of $S \$ 76.7$ billion and profit attributable to equity holder of Temasek of $\$ \$ 4.6$ billion for the year ended on March 31, 2010. The Temasek's results of operations are materially affected by conditions in the global capital markets and the economy generally, both in the U.S. and elsewhere around the world. Negative trends in these factors led to declines in Temasek Group's revenue and profit. In the event of extreme prolonged market events, such as the global credit crisis, the Temasek Group could incur significant losses. The following tables (see Table 3 and Table 4) sets forth selected income statement and balance sheet data for the Temasek for the years indicated. 
The global economy has experienced stress since the second half of 2007. Since then, concerns over inflation, energy costs, geopolitical issues, the availability and cost of credit, declining business and consumer confidence, and increased unemployment have slowed global economic growth and have resulted in recessions in numerous countries, including the U.S. and many countries in Asia. Global capital markets have also been experiencing heightened volatility and turmoil, and in the second half of 2008, the volatility reached unprecedented levels. The weak global economic conditions continued in 2009. While showing signs of improvement, the macroeconomic environment in 2010 remained for the Temasek difficult. In 2011 economic environment remains challenging with significant uncertainty regarding the outcome of the debt crisis in Europe, unemployment levels, and the impact of the unwinding of stimulus measures by the U.S. and other governments. The following chart (see Figure 5) describes mid-term decreasing profitability of the Temasek investment portfolio for the years indicated as an impact of the economic recession and worsened economic condition described above in the text.

Table 3

Temasek Selected Income Statement Data

\begin{tabular}{|c|c|c|c|}
\hline (S\$ million) & 2010 & 2009 & 2008 \\
\hline Revenue & 76,658 & 79,615 & 83,284 \\
\hline Net operating expenses & $-72,570$ & $-72,448$ & $-63,125$ \\
\hline Share of profit, net of tax of associated companies, and joint ventures & 4,387 & 3,202 & 5,370 \\
\hline Profit before income tax & 8,475 & 10,369 & 25,529 \\
\hline Income tax expense & $-1,682$ & $-1,280$ & $-3,056$ \\
\hline Profit for the year & 6,792 & 9,089 & 22,474 \\
\hline \multicolumn{4}{|l|}{ Attributable to } \\
\hline Equity holder of Temasek & 4,593 & 6,183 & 18,240 \\
\hline Minority interests & 2,199 & 2,906 & 4,234 \\
\hline Profit for the year & 6,792 & 9,089 & 22,474 \\
\hline
\end{tabular}

Note. Source: Temasek annual reports of 2010, 2009, and 2008.

Table 4

Temasek Selected Balance Sheet Data

\begin{tabular}{|c|c|c|c|}
\hline (S\$ million) & 2010 & 2009 & 2008 \\
\hline \multicolumn{4}{|l|}{ Assets } \\
\hline Property, plant, and equipment & 67,974 & 68,206 & 75,302 \\
\hline Investments & 44,610 & 41,105 & 39,513 \\
\hline Non-current financial assets and derivative financial instruments & 64,181 & 40,234 & 73,850 \\
\hline Other assets & 37,918 & 37,445 & 38,285 \\
\hline Current assets & 70,109 & 60,958 & 68,568 \\
\hline Total assets & 284,793 & 247,949 & 295,518 \\
\hline \multicolumn{4}{|l|}{ Liabilities and total equity } \\
\hline Equity attributable to equity holder of Temasek & 149,743 & 118,398 & 144,058 \\
\hline Minority interests & 23,409 & 22,555 & 25,786 \\
\hline Non-current liabilities & 69,610 & 64,438 & 59,220 \\
\hline Current liabilities & 42,031 & 42,558 & 66,454 \\
\hline Total equity and liabilities & 284,793 & 247,949 & 295,518 \\
\hline
\end{tabular}

Note. Source: Temasek annual reports of 2010, 2009, and 2008. 


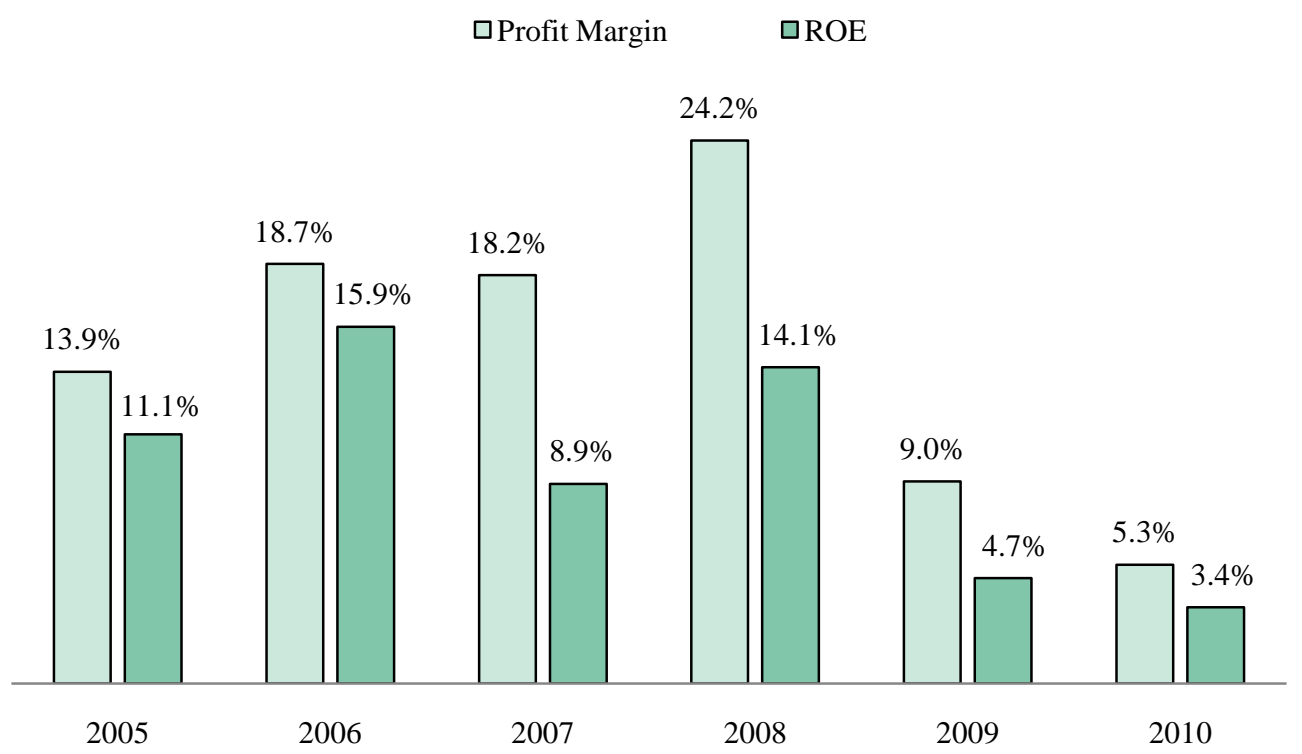

Figure 5. Temasek profit margin and ROE development over time.

\section{Conclusions}

This paper presents information about investment strategy one of the most successful SWFs on the world-Temasek Holding. The paper also analyzes the main investments holdings in the Temasek portfolio. Also it examined historical financial performance and described main risk tools what are used by Temasek. It is found that sovereign wealth fund can provide significant performance over long-term period and SWFs can be a significant part of the economy.

The main factor behind the growth of SWFs is the effort by many emerging market countries to accumulate large stockpiles of international reserves by running persistent current account surpluses. Many of these countries, particularly in Asia, now hold more reserves than needed for prudential reasons. As can be seen in this paper, attempts to diversify these reserves into potentially higher-yielding assets entail transferring them from the control of the central bank to quasi-public entities, such as SWFs, with the mandate to pursue financial strategies aiming at higher long-run returns.

SWFs are fundamentally different from monetary authorities holding official foreign reserves, where liquidity and security issues necessitate a short investment horizon and low-risk tolerance. As can be seen, SWFs typically seek to diversify foreign exchange assets and earn a higher return by investing in a broader range of asset classes.

By definition, the global sum of all current accounts adds up to zero. Hence, the still growing current account surpluses of commodity exporters and Asian countries will be the mirror image of the growing current account deficits of other countries, primarily the U.S. and the EMU. Excess saving and accumulation of foreign assets by surplus countries will be the counterpart to the excess demand and issuance of foreign liabilities by deficit countries. The result, growing international wealth transfer from debtors in one country to creditors in others will foster the growth of SWFs in to the future. 


\section{References}

Aizenman, J. (2008). Large hoarding of international reserves and the emerging global economic architecture. The Manchester School, 76, 487-503.

Balding, C. (2008). A portfolio analysis of sovereign wealth funds. Retrieved February 15, 2010, from http://www.papers.ssrn.com/sol3/papers.cfm?abstract_id=1141531

Brigham, E. F., \& Ehrhardt, M. C. (2005). Financial management. Manson: Thomson South-West.

IMF (2008). Sovereign wealth funds-A work agenda. Retrieved March 18, 2010, from http://www.imf.org/external/np/pp/eng/2008/022908.pdf

Johnson, S. (2008). The rise of sovereign wealth funds. Boston College Financial, 3(1), 6-9.

Temasekreport. (2010a). Temasek annual report 2010. Retrieved February 10, 2010, from http://www.temasekreport.com/2010/documents/full_annual_report2010.pdf

Temasekreport. (2010b). Temasek annual report 2009. Retrieved February 10, 2010, from http://www.temasekreport.com/2009/documents/full_annual_report2009.pdf

Temasekreport. (2010c). Temasek annual report 2008. Retrieved February 10, 2010, from http://www.temasekreport.com/2008/documents/full_annual_report2008.pdf

Ziemba, R. (2008, April). So how large are sovereign wealth funds? Roubini Global Economics Monitor. Retrieved March 18, 2010, from http://www.economonitor.com/analysts/2008/04/02/so-how-large-are-sovereign-wealth-funds/ 